\title{
Trade unions, immigration and immigrants in Europe revisited: Unions' attitudes and actions under new conditions
}

\author{
Stefania Marino ${ }^{1 *}$, Rinus Penninx ${ }^{2}$ and Judith Roosblad ${ }^{2}$
}

\author{
* Correspondence: \\ stefania.marino@mbs.ac.uk \\ ${ }^{1}$ European Work and Employment \\ Research Center (EWERC), \\ Manchester Business School, \\ University of Manchester, \\ Manchester, UK \\ Full list of author information is \\ available at the end of the article
}

\begin{abstract}
This paper revisits the comparative approach used by Penninx and Roosblad (Trade Unions, Immigration and Immigrants in Europe, 1960-1993. New York: Berghahn Books) to study trade unions' attitudes and actions in relation to immigrant workers in seven Western European countries. It reassesses that approach and asks whether it remains valid, as economic, social, and political circumstances nowadays seem fundamentally different from those two to five decades ago. Each element of the original conceptual and explanatory frame is reassessed and its suitability weighed for an updated comparative study. The reassessment combines insights from migration studies with findings from the field of industrial relations. The latter highlight internal union variables in explaining trade unions' attitudes and actions, while the former underline trade unions' role as social and political actors in defending migrant rights.
\end{abstract}

Keywords: Immigration; Migrant workers; Trade unions

\section{Introduction}

Migration has become a controversial issue in most European countries. Immigrants are often blamed for society's problems. They are perceived as outsiders who take jobs, sponge welfare benefits, and threaten social cohesion. These fears have been intensified by economic recession, high joblessness, and the rise of flexible forms of employment. Indeed, divisive nationalist arguments, labour conflicts, and episodes of violence have become dangerously manifest in many societies. As a consequence, immigrant integration - under conditions set by receiving societies - has become a major issue for governments at all levels (Penninx et al., 2006).

Trade unions have to take positions on these matters, both based on their own convictions and interests and as actors in the labour market regulatory framework. Unions' standpoints are thus likely to affect the position of migrant workers within the labour market and within society. Trade unions' attitudes and actions related to migrant workers therefore constitute a relevant area of inquiry in both migration studies and industrial relations research. Within migration studies, such analyses would provide insights on the role of trade unions in promoting immigrants' labour market and social integration. In industrial relations, a better understanding of the relationship between unions and migrant workers would advance the debate on trade union revitalization strategies (Frege and Kelly, 2003; Behrens et al., 2004). Furthermore, comparative 
analyses on this topic could produce new insights on the effects of supranational dynamics on national questions of migration and integration policy. Finally, comparative study might increase our understanding of how employment relations systems function and the role and position of labour organizations within them.

Recent systematic cross-country comparisons of trade unions' activities in this field have been either quantitative in nature (Gorodzeisky and Richards, 2013) or focused on a limited number of countries (e.g., Krings, 2009; Hardy et al., 2012). In this respect, the qualitative cross-country comparison by Penninx and Roosblad (2000) - two of the present authors - still constitutes a unique example. Their book, entitled Trade Unions, Immigration, and Immigrants in Europe, 1960-1993, offers a comparative analysis of the relationship between trade unions and immigrant workers in seven North-Western European countries, while attempting to account for differences in trade union strategies and actions. That book has become a classic reference on the topic, and its conceptual framework has been widely adopted (e.g., Krings, 2009; Wrench, 2004; Marino, 2012). Since the publication of that study, however, major contextual changes have taken place, necessitating revalidation of the original theoretical and epistemological framework. The current paper thus revisits the framework in light of contextual changes and insights from recent literature. The aim is to suggest an updated instrument for systematic, qualitative, cross-country comparisons.

The first section of this paper outlines the original heuristic model used by Penninx and Roosblad (2000). The second sketches the contextual changes that we believe impact trade unions, especially their positions and strategies. The final section draws conclusions for the study of the new challenges facing trade unions nowadays and the potential roles of unions related to immigrants and immigrant integration in Europe.

\section{The original heuristic model and its outcomes}

The original analytical framework contains three basic dilemmas that guide the comparative description and four sets of explanatory factors to account for differences in outcomes. The first dilemma is whether trade unions should resist employers' efforts to recruit workers from abroad or to cooperate. If unions do cooperate, it asks what terms they should try to establish for employment of foreign workers. Cooperating could, after all, depress wages of union members, and availability of surplus labour might weaken trade unions' bargaining power. Yet, resisting could slow economic expansion.

The second dilemma arises when immigrant workers actually arrive, regardless of whether they come 'spontaneously' or are recruited: should immigrant workers be regarded as an integral part of the trade union rank and file and therefore be actively recruited as members with the same rights as any worker? The alternative is to exclude foreign workers partially or completely from union membership. Exclusion could drive a wedge into the labour movement, eventually weakening its negotiating position. Inclusion, however, might be seen as a threat to national labour markets and trade union interests and thus clash with the interests of native workers (or be perceived as such).

If trade unions favour inclusion as a solution to the second dilemma, then the real or alleged differences between native and immigrant workers leads to the third dilemma, that of equal versus special treatment: should trade unions exclusively represent the 
common interests of native and migrant workers, treating all workers the same? Or should they develop targeted policies and strategies that cater to the special interests and needs of migrant members? While generalized strategies may implicate injustices, specialized policies risk alienating native members, who might resent such 'preferential treatment'.

To explain differences between trade unions' attitudes and actions, Penninx and Roosblad (2000) propose four sets of factors. The first is the power that trade unions have in society and in national socio-economic decision-making. The more powerful a trade union is, the more effective it will be in influencing the policies of government and employers' associations in union-advocated directions.

The second set of factors involves the economy and labour market conditions. In times of ample national supply of labour, trade unions are likely to oppose recruitment of immigrant workers; while in times of labour shortages, unions will probably be more willing to cooperate. The state of the economy and labour market might also influence trade unions' responses to the second and third dilemmas. In times of widespread unemployment, competition (actual or presumed) between indigenous and immigrant workers might increase, making inclusive union policies difficult to maintain.

The third set of factors relates to social trends. Trade union policies towards immigration and immigrants are influenced by contextual aspects such as public discourse, institutional arrangements, legislation, and institutional actors like national authorities, civil society organizations, and political parties.

The final set of factors concerns the characteristics of immigrants and public perceptions thereof. Unions may be more sympathetic to immigrants from former colonies, to those from countries where unions hold similar ideologies, and to those perceived as culturally similar to the indigenous population. Immigrants may also themselves have characteristics that influence their ability or willingness to unionize. These include experiences with trade unions in the country of origin and their educational level, legal status, and duration of stay.

The findings of Penninx and Roosblad's descriptive comparative analysis can be summarized by saying that - notwithstanding similar worries and solidarity commitments among trade unions in the seven countries studied - reactions to immigration and immigrants differed significantly between 1960 and 1993. For our purposes here, it is relevant to review how well the proposed explanatory factors accounted for variation between the trade unions in their responses to the three dilemmas. In fact, Penninx and Roosblad concluded that these factors only partially explained the variation between trade unions. In both Germany and Austria, for instance, trade unions had a strong position in socio-economic decision-making, but this did not predict the content or direction of union policies towards immigration and migrant workers. The Swiss and French unions - both weak in co-decision-making - did not take the same position either.

As for the influence of economic factors, evidence was equivocal. In the period of economic recession following the 1973 crisis, trade unions in all countries established new alliances with state authorities towards restrictive immigration policies. However, economic decline triggered a wide spectrum of responses regarding the integration process. While some unions (e.g., the Austrian and Swiss) argued that the recession offered no latitude for representation of the special interests of immigrants, others were 
less inclined to focus one-sidedly on the state of the economy to the neglect of social trends. The Dutch trade unions, for example, drew up internal policies on minorities in the early 1980s, which was a period of economic recession and high unemployment (Roosblad, 2002).

This last example underlines the varying outcomes of the third factor - the influence of social trends. Whereas in the Dutch and the Swedish cases trade unions followed government's progressive integration policies in the 1980s, unions in the FRG established coalitions with other societal actors against government policy that aimed for the return of workers rather than their integration.

As for the influence of immigrants' characteristics, little evidence of a direct relationship emerged. Variations in overall union membership, especially of immigrant workers, seemed attributable to unions' institutional embeddedness in the national context. For example, unionization rates of Turkish immigrants were found to be lower in the Netherlands than in Germany and Sweden, reflecting overall unionization rates in those countries.

These findings indicate that the explanatory factors intersect. In all countries, trade union policies towards immigration and immigrants proved to be influenced by national contextual factors such as public discourse, institutional arrangements, legislation, and key institutional actors like national authorities, churches, and political parties. Although trade unions may ideologically have an internationalist orientation, their actual effectiveness is determined within national contexts (Penninx and Roosblad, 2000: 206). Therefore, the way the dilemmas are resolved cannot be understood without knowledge of these national contexts.

The changing context for European trade unions and immigrant integration, 1993-2013 Penninx and Roosblad (2000) centres on the post-war guest-worker system in North-Western Europe and its aftermath until the early 1990s. Since that period, major changes have taken place, in migration and integration and in labour-related domains such as the international economic order, national and international labour markets, industrial relations, and perhaps especially, the position of trade unions.

\section{Changing migration patterns and policies}

In the past decades, the general picture of international migration in Europe has changed completely, in terms of its size and patterns and in terms of its regulation.

First of all, migration flows have strongly increased, from an estimated 23 million immigrants in 1985 (UN 1998: 1) to more than 56 million, or 7.7 per cent of the total European population in 2000 (IOM 2003: 29). In the present 28 members of the European Union (EU), nearly 49 million of the total of 504 million inhabitants are foreign-born (including those born in other EU countries). This is some 10 per cent of the total population (Eurostat 2012: 1). Moreover, these figures include only legally residing foreign-born persons.

Early in the period studied by Penninx and Roosblad (2000), immigration started in the countries of North-Western Europe. Other countries, such as Italy, Spain, Portugal, Greece, Ireland, Norway, and Finland, were emigration countries until the 1980s but began to experience significant immigration in the 1990s and 2000s. Yet others, among them most of the post-2004 EU accession countries, have experienced simultaneous emigration, transit migration, and immigration. Europe has in fact become an immigration continent. 
A novel characteristic of recent migration lies in what is called the 'new geography' of migration (King, 2002). The origins of migrants in Europe up to the 1980s could conveniently be grouped under three headings: (i) colonial migration, which connected certain European countries to their former colonies; (ii) labour migration, which connected 'recruiting countries' and 'sending countries'; and (iii) refugee migration, which was strongly dominated by migration from East to West Europe. That picture changed completely after 1990. Nowadays, immigrants come to Europe from all over the world and for various reasons. Expatriates come to work at multinational companies and in international organizations; foreign students come to attend higher education; nurses and doctors arrive to work in national healthcare facilities; refugees and asylum seekers come from Africa, the Near East and Asia, the Balkans, and former Soviet Union countries; and undocumented workers arrive from the developing world.

Another novel characteristic today is the feminization of labour migration. More women migrate independently for labour purposes, and not as dependants in family reunifications. This is particularly relevant for trade unions, since it corresponds with the development of labour market niches, such as domestic services, care and nursing, and the sex industry. Gendered connections have thus developed between immigrants' offerings of labour, labour market demands, and the status of the workers concerned.

Types of mobility have also changed. There is increased mobility among seasonal workers in agriculture and tourism, among students, pensioners, 'posted' workers, and skilled professionals. Mobility of these 'desired' travellers is now facilitated, if not promoted outright. But there are also unsolicited migrants in search of economically better or politically safer destinations for whom new and increasingly onerous barriers have been erected.

This brings us to another fundamental change: that of the regulation of international migration. Since the mid-1970s, countries have introduced restrictive migration policies in line with their diminished demand for (low-skilled) migrant workers. Yet, this same period has seen increased migration for family reunion and formation, refuge, and asylum. Since the early 1990s, further barriers have been erected through stricter visa policies, tougher requirements for legal residence, and higher refusal rates for asylum seekers. In a spiral of cause and effect, new restriction and control measures have stimulated 'innovative' forms of entrance (like smuggling and trafficking), which in turn have led to newly restrictive and control-oriented admission requirements and procedures. Immigration has increasingly been criminalized. Yet, the tougher the regulations, the more they have led to illegality and irregularity. The spectre of terrorism has further promoted this security perspective. Anti-terrorism policies have been primarily government initiatives. For their implementation, however, involvement of employers, trade unions, and other civil society organizations is required, with control practised at the borders of the country of origin and with carriers (airlines, sea ferries, and transport firms) liable for infringements.

At the supranational level, the EU has become a significant political and policy unit, creating a new context for mobility and migration in Europe, particularly since the 1997 Treaty of Amsterdam. EU member states, particularly the 'old' ones, have promoted common restrictive and defensive admission policies in relation to potential immigrants from non-EU countries. Furthermore, new member states are required to enact legislation and establish institutions in conformity with established EU policies in this domain. This strand of EU policies has been derided by critics as building 'Fortress Europe'. 
Measures have been introduced to regulate access to the labour market and other institutional domains of welfare states. These regulations, and the associated controls on both workers and employers, function as a second 'border', rendering the welfare state inaccessible to illegally residing immigrants.

In parallel, the EU has established a fundamental right to move and settle within the EU area for EU citizens and long-term Third Country Nationals (TCN). The EU free movement area now encompasses 28 countries with a total population of more than half a billion. An increasing share of these inhabitants are 'internal EU migrants', most of whom are workers. The financial and economic crisis since 2009 has reinforced the dominance of intra-EU labour migration, as the German case illustrates (Sachverständigenrat, 2013: 54). Nonetheless, migrant workers from the newest EU member states tend to be employed in precarious and dangerous jobs (Woolfson and Likic-Brboric, 2008). These workers (and foreign workers in general) arguably serve as a 'hyper-flexible buffer' since 'being disposable in case of downturn, [they] can carry most of the uncertainty burden without causing political problems' (Meardi et al., 2012: 7). Increasing unemployment in the southern EU countries and in Ireland may promote further intra-European circular mobility in coming years.

Another form of cross-border mobility encouraged by the liberalization of services provision emerged in the 1990s under the category of 'posted workers'. These are employees sent by their employers to work temporarily in another country (labour laws of the country of origin apply for such stays). Fears that such arrangements might be abused to evade national labour laws resulted in adoption in 1996 of the EU Posted Workers Directive (PWD), followed by intense debate regarding prevention of 'social dumping' (see, e.g., Cremers et al., 2007).

These changes in migration patterns and regulation are common to most European countries, but their impacts do differ in specific national contexts. First of all, immigration flows have different characteristics across countries. Immigration towards North-Western Europe, for example, stems mainly from family formation and reunification, asylum seekers, and knowledge workers. Yet, as a consequence of strict admission policies, these countries have started to experience larger influxes of undocumented migrants too. Since 2004, they have also experienced increased intra-EU migration, especially from the new EU member states.

Immigration to Southern European countries such as Italy, Spain, Portugal, and Greece mainly consists of labour migrants from Central and Eastern Europe, North Africa, Latin America, and Asia. Most come unsolicited, many without proper documents at first; many are legalized in the course of time. In Italy, 1.7 million undocumented residents were regularized between 1986 and 2009 (Zincone, 2011: 249). In Spain, regularization has been called 'the easiest and most common way to obtain a legal status' (Bruquetas-Callejo et al., 2011: 305). Due to their vulnerable position in the host country, such migrants are not in a position to refuse low wages and substandard social and labour rights (King, 2000: 18). Many therefore end up in the informal economy.

\section{Changes in labour markets and industrial relations}

Labour markets and industrial relations have also changed significantly, affecting trade unions and their relations to immigrants. Firstly, economic and financial globalization has challenged national economies and their regulatory frameworks, within which trade 
unions have developed their positions of influence. 'Regime shopping', by which multinational enterprises move to countries with less onerous regulatory regimes, increasingly constrains governments and national economic policy (Streeck, 1992). Many nation states have loosened regulations, including those pertaining to labour, in order to remain or become attractive to enterprises. Furthermore, national economies have become intertwined with global financial markets. Thus, the outbreak of the financial crisis in 2007 affected the entire world economy, impacting employment and labour regulations across Europe. Trade unions have very little direct influence on supranational developments, but they do strongly feel the consequences at the national level.

Secondly, the structure of labour markets has changed. The primary sector has shrunk to insignificance. In the secondary sector, the number of jobs in manufacturing (where unions used to be strongest) has diminished, and the qualifications demanded of workers have changed markedly. The service sector has become the main employer with a great diversity of required qualifications and a spectrum of legal and regulatory statuses (including many precarious jobs). Privatization and outsourcing of public services (another sector in which unions are traditionally strong) have contributed to these diversities. Furthermore, employers' pressure for more labour flexibility and labour market deregulation have given rise to new forms of employment, such as temporary and part-time work, often organized through agencies, subcontracting, and hiring of self-employed workers. Trade unions were traditionally most active in regulation of standard employment. They must now define and represent the interests of a more flexible and less homogeneous labour force, and do so without straining relationships with their traditional rank and file (Gumbrell-McCormick, 2011).

Thirdly, industrial relations and the position of trade unions have changed. Trade unions in most countries have less influence in socio-economic decision-making due to the generally declining capacity to steer national economies, and in some cases also because neoliberal governments have clamped down on unions (Crouch, 1997; Roosblad, 2013). Union membership has declined too, especially in certain segments of the labour market and among young and temporary workers. Diminished membership is most marked in the private sector, while rates of unionization in the public sector remain generally higher (Visser, 2013). Due to these trends, union membership composition is less and less representative of the structure of the overall labour force (Ebbinghaus, 2004; Gumbrell-McCormick and Hyman, 2013).

\section{Towards a refined heuristic model}

If we were to begin new cross-country comparative research on trade unions' responses to immigrants, what guiding concepts and ideas could we distil from the foregoing sections? Is the heuristic approach by Penninx and Roosblad (2000) still useful today in the face of the above mentioned changes? Or should it be redefined to reflect the increased complexities?

\section{Revisiting the dilemmas}

As to the first dilemma - whether trade unions should cooperate or resist recruitment of migrant workers - we must conclude that the conditions under which trade unions face this dilemma have changed. First, migration has become an important feature of more European countries, not just those in North-Western Europe. Secondly, 
nowadays trade unions are much less involved in corporate decision-making, particularly regarding immigration. Labour migration is overall no longer a major focus of decision-making for national labour markets ${ }^{1}$. Thirdly, more immigration takes place under the free movement regime within the enlarged EU, in which a completely new set of rules applies (though these do not influence trade unions directly).

The dilemma nowadays is whether trade unions, as social and political actors, should try to influence regulations on immigration and migrant workers' access to labour markets by opposing or supporting government policies on immigration and integration. In fact, most European trade unions have formally abandoned their restrictive stances of the past. They have 'renewed' their emphasis on notions such as international solidarity and equality and tend to favour more liberal immigration regimes. Some Southern European trade unions have lobbied against national immigration laws that they perceived as unfair and discriminatory and have supported regularizations of undocumented immigrants. In countries such as Spain and Italy, however, these stances have been explained in terms of protecting the national workforce and advocating for better labour conditions (Watts, 2002). A similar interpretation was recently proposed to explain unions' attitudes in some North-Western European countries (Menz, 2009).

In other cases, and despite a formal rhetoric of inclusiveness, exclusionary union attitudes are justified by concerns about a 'race to the bottom'. Some West European trade unions, for instance, actively opposed the free movement of labour within the EU and lobbied for transitional arrangements after the 2004 enlargement. Speaking about Germany and Austria, Krings (2009: 56) states, 'Unions in both countries stressed that their opposition to the free movement of labour should not be viewed as "anti-immigration", but that their main concern was the preservation of labour standards'. Other scholars underline the risk of conflicts between eastern and western trade unions due to their diverging interests during the accession process (Meardi, 2002; Galgóczi et al., 2009). These examples show that, despite formal declarations of international solidarity, trade unions' dominant frame of reference remains the national arena. Their stances on immigration often cite concern to protect the national labour market from social dumping (Cremers, 2011; Meardi, 2012; for a perspective from the sending countries, see Woolfson, 2007). These stances are strikingly similar to those reported in the earlier Penninx and Roosblad study. This leads us to conclude that the first dilemma is still valid, though it should be applied in a broader sense.

The second dilemma - inclusion versus exclusion - has certainly been affected by the contextual changes mentioned earlier. First, trends in industrial relations, particularly the weakened position of trade unions, have triggered attempts to revitalize unions (Frege and Kelly, 2003), with inclusion of immigrant workers (among other underrepresented groups) being a foremost strategy (Behrens et al., 2004). Yet the success of such a strategy 'may depend on changing the attitudes and expectations of existing membership. This may be especially true if external recruitment involves targeting new demographic groups that will change the membership composition and might be resented by the existing membership core' (ibid.: 21). In this respect, the 'old' dilemma is still valid.

Organizing campaigns have been particularly successful in the United States, where they have helped to reconnect the labour movement with its rank and file (Milkman, 2006). In Europe, such organizing has been implemented in the United Kingdom (see, 
e.g., Heery et al., 2000; Holgate, 2004, 2005; Martínez-Lucio and Stuart, 2009; Simms et al., 2013) and more recently in the Netherlands (Günther, 2010; Connolly et al., 2011). While sometimes successful in gaining better conditions for the workers involved, the extent to which these strategies have promoted effective and full inclusion of immigrant workers in union membership remains uncertain.

The growth of intra-EU mobility, in the form of free movement and posted workers, also affects the inclusion-exclusion dilemma, since it gives new impetus to the 'old' debate regarding whether today's migrants should be included as trade union members, considering the 'temporary' nature of much current mobility as well as increased concern about social dumping. In this respect, the literature provides examples of trade unions trying to organize new migrants (see, e.g., Fitzgerald and Hardy, 2010; Heyes, 2009; James and Karmowska, 2012). However, much of the emphasis has been on the need to create networks with communities and to provide language facilities, both instruments aimed at facilitating relationships (and diminishing tensions) between foreign and local workers. Instead the recruiting and organizing migrant workers remained weak due to the temporary nature of their immigration (Fitzgerald and Hardy, 2010).

With respect to the posting of workers, trade unions have found themselves in difficult positions situations as shown, for instance, by the mobilization against foreign contract workers in the Laval case in Sweden (Woolfson, 2007) and the Lindsay Oil Refinery case in the United Kingdom (see Barnard, 2009; Meardi, 2012).

Migrants have also become a much more complicated entity for trade unions, particularly due to greater variation in their legal, labour market, and social statuses, resulting in a process of 'civic stratification' (Lockwood, 1996). Furthermore, antiimmigrant and populist political discourse and the inadequacy of administrative facilities often leave migrants in vulnerable positions. Trade unions may thus be called upon to face a complex of problems, well beyond labour claims and labour equality to also, increasingly, involve social and legal status. This is especially true for the significant share of migrants who are irregular and undocumented. Most activities related to vulnerable and undocumented workers, in fact, necessarily involve aspects not strictly labour-associated. Examples are assistance in regularization of residence and labour and gaining access to housing and public services. Beyond exerting political pressure on government, trade unions in Spain and Italy have provided direct support, setting up structures and front offices for migrant worker assistance (see Martínez-Lucio et al., 2013; Marino, 2012). In France, trade unions have called attention to the legal and social conditions of immigrants, using strikes to influence government decisions on legalization of residence and work status.

In cases where trade unions have undertaken action such as assistance to undocumented workers (Julliard, 2010; Nicholls, 2010) and where trade unions have helped those workers to organize (Günther 2010; Wills, 2008), the third dilemma gains a new face too. Trade unions have to take the special characteristics of immigrants into account as a precondition for cooperation. Yet, such special characteristics are related less to cultural traits than to the immigrants' structural and legal position in society. Therefore, alongside targeted facilities such as learning or language services (see, e.g., Martínez-Lucio and Perrett, 2009a), a much wider set of policies and practices is needed to promote inclusion in social and political terms. The Italian and Spanish trade unions offer examples of actions that can be taken in this regard. Working towards 
solutions for practical problems also implies an awareness of the strategic importance of the broader social context for union activism. New forms of action, such as community-based organizing (Martínez-Lucio and Perrett, 2009b; Wills and Simms, 2003), make the neighbourhood, rather than the workplace, the focus of union intervention.

The third dilemma - equal treatment or special strategies and policies - thus remains fundamental even when more 'traditional' forms of inclusive policies are adopted, such as organizing migrant workers. Whether such policies succeed in providing immigrant workers greater voice and fuller inclusion within trade unions through, for example, organizational changes, more democratic procedures, and specific structures for them to influence decision-making, is a question for further research (see Mustchin, 2012; Martínez-Lucio and Perret, 2009a).

Changes in how these three dilemmas play out nowadays imply one fundamental novelty: trade unions today must act as a civil society actor in favour of immigrants rather than as a strictly labour-related interest body. This civic and political engagement requires a rethinking of strategies and coalitions as well as a willingness to promote internal organizational and cultural changes (Hyman and Gumbrell-McCormick, 2011).

The foregoing observations lead us to propose a wider concept of 'inclusion', that being 'full recognition of migrant workers as having the same social, employment, political and "organisational" rights as all other workers and members, being able to join the organisation at all levels and to participate in both internal debates and the formation of general strategies' (Marino, 2013: 54). This definition implies the adoption of special policies and measures addressing the position of migrant workers both within unions and in the wider social sphere, in the labour market, and in the workplace. From an analytical viewpoint, this implies that the 'equal versus special treatment' dilemma should be expanded by considering three additional choices: (i) what rights should trade unions defend, merely industrial rights or social rights as well; (ii) how should trade unions defend these rights, solely by bargaining activities or also by political action; and (iii) how should trade unions organize immigrants and their interests internally, through a unitary model that excludes any special cultural backgroundbased body or by a pluralist model that encourages and supports the formation and internal influence of such bodies (ibid.).

\section{Revisiting the explanatory factors}

We saw in the previous section that the four sets of factors in Penninx and Roosblad (2000) had limited explanatory power separately. But the factors combined in a given national context did help us to understand the differences between trade unions' attitudes and actions. Indeed, empirical evidence drawing on the original theoretical framework confirms that the four factors cannot be treated as monocausal explanations (see, e.g., Wrench, 2004; Krings, 2009; Marino, 2012). That same evidence, however, leads us to reformulate and refine the sets of explanatory factors.

The first set of factors individuated by Penninx and Roosblad (2000: 13-14), the power position of trade unions in society, was strongly linked to the position of trade unions in national socio-economic decision-making processes. Trade unions were considered more powerful (at the national level) if they were highly organized; if they 
maintained strong ties with governing political parties; and if they had a strongly centralized and unified structure. Recent research presents interesting findings in this respect. Studying trade union responses to immigrants in Denmark and the United Kingdom, Wrench (2004: 21) argues that these operate contrary to the predictions of Penninx and Roosblad (2000):

The Danish trade union movement has a far higher membership rate and far greater political influence than its British counterpart, yet is relatively inactive against discrimination. The British trade union movement, already weak in comparison to Denmark, adopted a stronger stance in favour of immigrants and against racial discrimination at a time when external forces were making it even weaker.

Wrench links the more inclusive stance on immigration and 'race' to a decline of union influence, 'as membership and power declined, it was increasingly recognized that the future of trade unionism depended on a more inclusive strategy which took seriously the problems and interests of previously marginalized groups' (Wrench, 2004: 21). Krings (2009) reports similar findings, analysing trade union responses to immigration in Austria, Germany, Ireland, and the United Kingdom. This author links a less inclusive trade union attitude in Austria, Germany, and Ireland to institutional entrenchment in terms of involvement in collective agreements and systems of social partnership that allow unions a formal role in socio-economic decision-making:

In Britain the collapse of traditional bargaining institutions and a loss in union influence under the Conservative governments propelled unions into rethinking traditional union strategies, not least in terms of organizing new groups of 'atypical' employees. This has contributed to a re-appraisal of union strategies towards more marginalized groups such as migrant workers (ibid.: 61-62).

Comparing Italian and Dutch trade unions, Marino (2012) suggests that a lesser institutional embeddedness of trade unions in national socio-economic decision-making (in the Italian case) is likely to strengthen unions' commitment to represent migrant workers. Roosblad (2013) supports this finding based on observations of Dutch trade unions during the past decade. She suggests that the current weakening of the institutional embeddedness of Dutch trade unions triggered them to start actively incorporating new groups of workers, such as undocumented workers, into their organization (ibid.: 47). Finally, based on a quantitative analysis of 14 West European countries, Gorodzeisky and Richards (2013) argue that the organizational security of trade unions, in the form of state financing or a single dominant trade union confederation, is inversely related to trade union incentives to organize migrant workers.

This empirical evidence suggests the presence of an inverse relationship between the degree of institutional embeddedness and inclusive attitudes towards migrant workers: institutional power tends to reduce trade unions' need to resort to the membership, thus lowering recruiting and organizing efforts towards underrepresented groups. This hypothesis finds confirmation within recent literature (Baccaro et al., 2003; Hassel, 2007). It seems to us, therefore, that the position of trade unions in society remains a potentially influential factor in cross-national differences, if we measure that position in a somewhat more open way: as the extent to which trade unions possess institutional power resources, including their embeddedness in society and in policymaking relevant to their potential rank and file, and including the coalitions that trade unions form to carry out their role as a political actor in society. 
With regard to economic and labour market factors, we concluded earlier that these are important triggers for trade union action, but that the direction of that action (beneficial or harmful to immigrants) is dependent on other contextual variables. Trade unions in Western Europe initially emphasized concerns about a 'race to the bottom' and 'social dumping' following the increase of foreign labour after the initiation of free movement of workers and services within the EU. The context was one of (perceived or real) increased labour market competition. Such observations point to dynamics similar to those described in Penninx and Roosblad (2000). The status of the labour market, therefore, still seems to be a fundamental factor of influence, although more attention should be given to transnational dynamics in Europe, particularly internal EU mobility. Specific attention must also be given to sectoral differences, both within and across countries. Immigration, labour market, and employment dynamics differ between sectors, and this will likely influence trade union activities (Arrowsmith, 2010). The presence and strength of trade unions within a sector is another consideration. This factor might influence the efficacy of inclusive action or the efforts and resources spent to include migrant workers, especially those in vulnerable, poorly regulated sectors with high levels of worker turnover (Gorodzesky and Richards, 2013). Here, the expected results in terms of membership increases are lower. Such illustrations lead us to suggest retaining economic and labour market factors, though again formulated in a more open way.

Regarding social trends, Penninx and Roosblad (2000) stress the importance of national contextual factors such as national identity and ideology, public discourse, legislation, and political structure and orientations. They find these to be influential, if only because the social characteristics of unions' rank and file members and their environment are integral to their existence. Wrench (2004) confirms that the contrast between the 'consensus and conflict frames of reference' and the quality of the national political discourse are important factors in explaining cross-national differences. This author especially stresses factors such as 'a more overtly racist, anti-immigrant, and Islamophobic discourse by political leaders and the media'. Indeed, elements such as racism, xenophobia, and recently Islamophobia, have received too little attention (Wrench, 2007). If they are widespread within trade unions and workplaces and if they are incorporated into union policies and practices, they imply either hostile attitudes towards, or disinterest in, migrant workers. If widespread throughout society and among workers, they might pose a dilemma to unions in interactions with their rank and file. In some cases, strongly anti-racist central policies may be paired with racism in workplaces, among workers, and among union delegates.

With regard to the last set of factors - characteristics of immigrants - we have good reason to rethink the importance of migrants' origin and earlier experiences with trade unions. Perhaps more relevant today are two types of characteristics of immigrants upon their arrival. The first is the labels given by state regulation to different kinds of immigration, determining immigrants' legal status and access to the labour market. The second is characteristics deriving from migrants' place and status on the labour market, for example, whether they are active in the formal or informal part of the economy, in new and still unorganized sectors, or in vulnerable work arrangements. Combining these two types of characteristics leads trade unions to do quite different things in practice to include illegal or undocumented workers, workers in sectors that were 
traditionally not or only partially organized (like domestic work), and workers in subcontracting and semi-independent relationships. For regular immigrant workers in traditionally organized sectors, the classic third dilemma that was formulated earlier - equal versus special treatment - is still valid. In these times of politicized and polarized discussions on immigration in most European countries, however, the equal treatment argumentation seems to win over the special treatment one. The question remains then to what extent will equal treatment lead to equal material outcomes for newcomers.

So we conclude that all four sets of factors - in amended form - are worthwhile to consider when explaining unions' attitudes towards immigration and immigrants nowadays. We believe, however, that it may be fruitful to complement these with an additional one: internal trade union dynamics. This may help us to understand the extent to which inclusive policies are implemented and might also help us to identify organizational barriers. The importance of internal dynamics is confirmed by many studies on trade union representation of migrant workers (e.g. Connolly et al., 2014). In analysing trade union involvement in the Living Wage campaign in London, Wills (2004), for instance, stresses that trade union efforts were influenced by the fit between these strategies and wider 'organizing priorities'. Similarly, Martínez-Lucio and Perrett (2009a) stress that trade unions' attitudes towards migrant workers are influenced by the specific ways unions perceive issues and build solutions based on interests, internal politics, and organizational capacities.

In our view, three internal variables deserve particular emphasis. The first one, 'trade union identity', consists of the inherited tradition that shapes trade union choices (Hyman, 1996). In this respect, Marino (2012) argues that the attitude of the Italian trade union federation CGIL (Confederazione Generale Italiana del Lavoro) towards migrant workers is strongly shaped by its identity as a 'general' union promoting defence of the social rights of 'disadvantaged groups' and engagement with problems not strictly related to employment. Similarly, the class-based identity of the Italian metal trade union FIOM-CGIL helps to explain its focus on employment rights and collective bargaining.

The other two interrelated variables are trade unions' structure and their internal communication processes, including decision-making procedures. As to the first, Penninx and Roosblad (2000) conclude that strongly centralized trade unions might have substantial influence at the national level, but at the same time be weak at the shop-floor level, which might undermine their ability to organize (immigrant) workers and to protect immigrants' interests in the workplace. Marino (2012) finds that decentralized structures facilitate planning and implementation of targeted policies and strategies suited to local circumstances and that a strong union presence in the workplace is important for acquiring an awareness of migrant workers' needs.

Gaining such awareness is strongly related to the second variable, internal communication processes. The presence of formal and informal instruments of bottom-up decision-making allows local measures and initiatives to be diffused to higher union levels and eventually become part of central union guidelines. In the Italian case, vertical linkages facilitated diffusion of organizational policies to the workplace (Waddington, 2000) and policy implementation was aided by balanced relations between central and decentralized levels and effective communication between them (Hyman, 1997; Kjellberg, 2000). By contrast, a centralized structure and merely top-down channels of communication and 
policy transmission - as in the Dutch case - worked against inclusion of migrant and ethnic minority workers.

\section{Conclusions}

This article critically re-examined the descriptive and explanatory framework used in an earlier comparative exercise (Penninx and Roosblad, 2000) in light of contextual changes and recent empirical research. It concludes that all three dilemmas are still valid, albeit with a somewhat different and wider interpretation in light of the changed context in which trade unions now operate. Beyond representing the interest of workers, trade unions must also consider their role as social and political actors. Their attempts to promote inclusion of migrants in a context of increasing institutional indifference and social hostility warrants more systematic study.

Regarding the explanatory framework, this article assessed the validity of the four sets of factors proposed by Penninx and Roosblad (2000), drawing on recent empirical research and reflections on the contextual changes in Europe during the past twenty years. We suggest extending the framework by including internal trade union variables, especially trade union identity, structure and the internal communication channels through which migrant workers' grievances might influence general union policies.

Competing interests

The authors declare that they have no competing interests.

Authors' contributions

All authors have actively participated in the writing of the article and have approved the final manuscript.

\section{Authors' information}

Stefania Marino is ESRC Research Fellow at the European Work and Employment Research Center (EWERC), Manchester Business School, University of Manchester, Manchester, UK.

Rinus Penninx is emeritus professor of Ethnic Studies and founder of the Institute for Migration and Ethnic Studies of the University of Amsterdam, Amsterdam, Netherlands.

Judith Roosblad is working at the Dutch Ministry of Social Affairs and Employment, and guest researcher at the

Institute for Migration and Ethnic Studies of the University of Amsterdam, Amsterdam, Netherlands.

\section{Acknowledgments}

The authors are indebted to the anonymous referees for their insightful comments.

This work was supported by the Economic and Social Research Council [grant number ES/K001752/1] and by

International Migration, Integration and Social Cohesion (IMISCOE) network.

\section{Note}

1. Trade unions and employers' associations may still be involved in negotiating the terms and conditions of recruiting and employing labour migrants in specific segments of the labour market. See, e.g., recruitment of foreign nurses in the Dutch health sector (Roosblad, 2005; De Lange and Pool, 2004).

\section{Author details}

${ }^{1}$ European Work and Employment Research Center (EWERC), Manchester Business School, University of Manchester, Manchester, UK. ${ }^{2}$ Institute for Migration and Ethnic Studies of the University of Amsterdam, Amsterdam, Netherlands.

Received: 13 February 2014 Accepted: 18 November 2014

Published online: 21 May 2015

References

Arrowsmith, J. (2010). Industrial relations in the private sector. In T Colling \& M Terry (Eds.), Industrial relations: Theory and practice (pp. 178-206). Chichester: Wiley.

Baccaro, L, Hamann, K, \& Turner, L. (2003). The politics of labour movement revitalization: The need for a revitalized perspective. European Journal of Industrial Relations, 9(1), 119-133.

Barnard, C. (2009). British jobs for British workers: The Lindsey Oil Refinery dispute and the future of local labour clauses in an integrated EU market. Industrial Law Journal, 38(3), 245-277.

Behrens, M, Hamann, K, \& Hurd, R. (2004). Conceptualizing labour union revitalization. In C Frege \& J Kelly (Eds.), Varieties of Unionism: Strategies for Union Revitalisation in a Globalizing Economy (pp. 11-30). Oxford: Oxford University Press.

Bruquetas-Callejo, M, Garcés-Mascareñas, B, Morén-Alegret, R, Penninx, R, \& Ruiz-Vieytez, E. (2011). The case of Spain. In G Zincone, M Borkert, \& R Penninx (Eds.), Migration policymaking in Europe: The dynamics of actors and contexts in past and present (pp. 291-326). Amsterdam: Amsterdam University Press. 
Connolly, H, Marino, S, \& Martínez-Lucio, M. (2011). Justice for Janitors' goes Dutch: The possibilities and limitations of an organising approach in the Netherlands. Paper presented at BUIRA conference (pp. 7-9). London: University of Greenwich.

Connolly, H, Marino, S, \& Martínez-Lucio, M. (2014). Trade union renewal and the challenges of representation: Strategies towards migrant and ethnic minority workers in the Netherlands, Spain and the United Kingdom. European Journal of Industrial Relations, 20(1), 5-20.

Cremers, J. (2011). In search of cheap labour in Europe: Working and living conditions of posted workers. Brussels: CLR/ EFBWW/International Books.

Cremers, J, Dølvik, JE, \& Bosch, G. (2007). Posting of workers in the single market: Attempts to prevent social dumping and regime competition in the EU. Industrial Relations Journal, 38(6), 524-541.

Crouch, C. (1997). The terms of the neo-liberal consensus. Political Quarterly, 68(4), 352-360.

De Lange, T, \& Pool, C. (2004). Vreemde handen aan het bed: De werving van Poolse verpleegkundigen in Nederland [Foreign hands at the bedside: Recruitment of Polish nurses in the Netherlands]. Migrantenstudies, 20(4), 130-144

Ebbinghaus, B. (2004). The changing union and bargaining landscape: Union concentration and collective bargaining trends. Industrial Relations Journal, 35(6), 574-587.

Eurostat. (2012). Population and social conditions. Statistics in Focus 31/2012. Luxemburg: Eurostat.

Fitzgerald, I, \& Hardy, J. (2010). Thinking outside the box? Trade union organising strategies and Polish migrant workers in the United Kingdom. British Journal of Industrial Relations, 48(1), 131-150.

Frege, C, \& Kelly, J. (2003). Union revitalization strategies in comparative perspective. European Journal of Industrial Relations, 9(1), 7-24

Galgóczi, B, Leschke, J, \& Watt, A. (2009). EU labour migration since enlargement: Trends, impacts and policies. Aldershot: Ashgate

Gorodzeisky, A, \& Richards, A. (2013). Trade unions and migrant workers in Western Europe. European Journal of Industrial Relations, 19(3), 239-254.

Gumbrell-McCormick, R. (2011). European trade unions and atypical workers. Industrial Relations Journal, 42(3), 293-310.

Gumbrell-McCormick, R, \& Hyman, R. (2013). Trade Unions in Western Europe: Hard Times. Hard Choices, Oxford: Oxford University Press.

Günther, S. (2010). From double illegality to double regularization: The unionization of (un)documented migrant domestic workers into Dutch trade unions. Amsterdam: Migrant Legality and Employment in Contemporary Europe.

Hardy, J, Eldring, L, \& Schulten, T. (2012). Trade union responses to migrant workers from the 'new Europe': A three sector comparison in Norway, Germany and the UK. European Journal of Industrial Relations, 18(4), 347-363.

Hassel, A. (2007). The Curse of Institutional Security: The Erosion of German Trade Unionism. Industrielle Beziehungen, $14(2), 176-191$

Heery, E, Simms, M, Delbridge, R, Salmon, J, \& Simpson, D. (2000). Union organizing in Britain: a survey of policy and practice. International Journal of Human Resource Management, 11(5), 986-1007.

Heyes, J. (2009). Recruiting and organising migrant workers through education and training: A comparison of Community and the GMB. Industrial Relations Journal, 40(3), 182-197.

Holgate, J. (2004). Black and minority ethnic workers and trade unions: Strategies for organisation, recruitment and inclusion. London: TUC.

Holgate, J. (2005). Organising migrant workers: A case study of working conditions and unionisation at a sandwich factory in London. Work, Employment and Society, 19(3), 463-480.

Hyman, R. (1996). Union identities and ideologies in Europe. In P Pasture, J Verberckmoes, \& H de Witte (Eds.), The lost perspective? Trade unions between ideology and social action in the new Europe. Volume 2: Significance of ideology in European trade unionism (pp. 60--89). Aldershot: Avebury.

Hyman, R. (1997). The future of employee representation. British Journal of Industrial Relations, 35(3), 309-336.

Hyman, R, \& Gumbrell-McCormick, R. (2011). Trade unions, politics and parties: Is a new configuration possible? Transfer, 16(3), 315-331.

IOM. (2003). World Migration 2003: Managing Migration: Challenges and Responses for People on the Move, IOM World Migration Report Series, No. 2. Geneva: International Organization for Migration.

James, P, \& Karmowska, J. (2012). Accommodating difference? British trade unions and Polish migrant workers'. Journal of Workplace Rights, 15(2), 169-189.

Julliard, E. (2010). The CGT and the French illegal immigrant workers' movement 2008-2009: When a union has to cope with the administrative criteria for legalization. Amsterdam: Paper for the ESF-seminar Migrant Legality and Employment in Contemporary Europe.

King, R. (2000). Southern Europe in the changing global map of migration. In R King, G Lazaridis, \& C Tsardanidis (Eds.) Eldorado or fortress? Migration in Southern Europe (pp. 1-26). Basingstoke: Macmillan.

King, R. (2002). Towards a new map of European migration. International Journal of Populations Geography, 8, 89-106.

Kjellberg, A. (2000). The multitude of challenges facing Swedish trade unions. In J Waddington \& R Hoffmann (Eds.) Trade unions in Europe: Facing challenges and searching for solutions (pp. 529-573). ETUI: Brussels.

Krings, T. (2009). A race to the bottom? Trade unions, EU enlargement and the free movement of labour. European Journal of Industrial Relations, 15(1), 49-69.

Lockwood, D. (1996). Civic integration and class formation. British Journal of Sociology, 47, 531-550.

Marino, S. (2012). Trade union inclusion of migrant and ethnic minority workers: Comparing Italy and the Netherlands. European Journal of Industrial Relations, 18(1), 5-12.

Marino, S. (2013). Between old and new dilemmas: Describing trade unions' inclusive strategies. In A van Heelsum \& B Garces-Mascarenas (Eds.), Filling in Penninx's heuristic model. Amsterdam: Amsterdam University Press.

Martínez-Lucio, M, \& Perrett, R. (2009a). The diversity and politics of trade unions responses to minority ethnic and migrant workers: The context of the UK. Economic and Industrial Democracy, 30(3), 1-24.

Martínez-Lucio, M, \& Perrett, R. (2009b). Meanings and dilemmas in community unionism: Trade union community initiatives and black and minority ethnic groups in the United Kingdom. Work, Employment and Society, 23(4), 693-710.

Martínez-Lucio, M. \& Stuart, M. (2009). Organising and union modernisation: narratives of renewal in Britain. In: G. Gall (ed.) Union revitalisation in advanced economies: assessing the contribution of union organizing. London: Palgrave/Macmillan, pp. 17-38. 
Martínez-Lucio, M, Marino, S, \& Connolly, H. (2013). Broadening and reimagining regulation: Trade unions, 'active servicing' and immigration in Spain since the early 1990s. The Journal of Industrial Relations, 55(2), 190-211.

Meardi, G. (2002). The Trojan horse for the Americanization of Europe? Polish industrial relations toward the EU. European Journal of Industrial Relations, 8(1), 77-99.

Meardi, G. (2012). Union immobility? Trade unions and the freedoms of movement in the enlarged EU. British Journal of Industrial Relations, 50(1), 99-120.

Meardi, G, Martin, A, \& Lozano Riera, M. (2012). Constructing uncertainty: Unions and migrant labour in construction in Spain and the UK. Journal of Industrial Relations, 54(1), 5-21.

Menz, G. (2009). The political economy of managed migration. Oxford: Oxford University Press.

Milkman, R. (2006). LA story: Immigrant workers and the future of the US labor movement. New York: Russell Sage.

Mustchin, S. (2012). Unions, learning, migrant workers and union revitalization in Britain. Work, Employment and Society, 26(6), 951-967.

Nicholls, WJ. (2010). The contradictory pathways to political integration: The case of France's undocumented immigrant movements. Amsterdam: Paper for the ESF-seminar Migrant Legality and Employment in Contemporary Europe.

Penninx, R, \& Roosblad, J (Eds.). (2000). Trade unions, immigration, and immigrants in Europe, 1960-1993: A comparative study of the attitudes and actions of trade unions in seven West European countries. New York/Oxford: Berghahn Books.

Penninx, R, Berger, M, \& Kraal, K (Eds.). (2006). The dynamics of international migration and settlement in Europe. A state of the art. Amsterdam: Amsterdam University Press.

Roosblad, J. (2002). Vakbonden en immigranten in Nederland (1960-1997) [Trade unions and Immigrants in the Netherlands (1960-1997)]. Amsterdam: Aksant.

Roosblad, J. (2005). Vissen in een vreemde vijver: Het werven van verpleegkundigen en verzorgenden in het buitenland. Enaringen met en toekomstverwachtingen over arbeidsmigratie in de zorgsector [Recruitment of nurses and caregivers abroad. Experiences and future expectations for labor migration in the health sector]. Working Paper 05/35. Amsterdam: Amsterdam Institute for Advanced Labour Studies.

Roosblad, J. (2013). Trade unions and the representation of migrant and ethnic minority workers: Challenges in deteriorating industrial relations. In A van Heelsum \& B Garces-Mascarenas (Eds.), Filling in Penninx's heuristic model. Amsterdam: Amsterdam University Press.

Sachverständigenrat deutscher Stiftungen für Integration und Migration (2013), Erfolgsfall Europa? Folgen und Herausforderungen der EU-Freizuegigkeit fuer Deutschland. Jahresgutachten 2013 mit Migrationsbarometer [Europe a successful case? Consequences and Challenges of EU-Free movement for Germany. Annual report with migration barometer]. Berlin: SVR. http://www.netzwerk-iq.de/fileadmin/redaktion/Publikationen/11_Literaturtipps/ SVR_Jahresgutachten_2013.pdf.

Simms, M, Holgate, J, \& Heery, E. (2013). Union voices: Tactics and tensions in UK organizing. Cornell: ILR Press.

Streeck, W. (1992). Training and the new industrial relations: A strategic role for unions? In M Regini (Ed.), The Future of Labour Movements (pp. 250-269). London: Sage.

UNITED NATIONS. (1998). Population Distribution and Migration. Proceedings of the United Nations Expert Group Meeting on Population Distribution and Migration, Santa Cruz, Bolivia, 18-22 January 1993. New York, United Nations.

Visser, J. (2013, April). ICTWSS: Database on institutional characteristics of trade unions, wage setting, state intervention and social pacts in 34 countries between 1960 and 2007. Retrieved on fill in the date and the year, from www.uva-aias.net/208

Waddington, J. (2000). Towards a reform agenda? European trade unions in transition. Industrial Relations Journal, $31(4), 317-330$

Watts, J. (2002). Immigration policy and the challenge of globalization: Unions and employers in unlikely alliance. Ithaca: Cornell University Press.

Wills, J. (2004). Organising the low paid: East London's wage campaign as a vehicle for change. In E Heery, P Taylor, \& W Brown (Eds.), The future of worker representation (pp. 246-282). Oxford: Oxford University Press.

Wills, J. (2008). Making class politics possible: organizing contract cleaners in London. International Journal of Urban and Regional Research, 32(2), 305-323.

Wills, J, \& Simms, M. (2003). Building reciprocal community unionism in the UK. Capital and Class, 82, $59-84$.

Woolfson, C. (2007). Labour standards and migration in the new Europe: Post-communist legacies and perspectives. European Journal of Industrial Relations, 13(2), 199-218.

Woolfson, C, \& Likic-Brboric, B. (2008). Migrants and the unequal burdening of 'toxic' risk: Towards a new global governance regime. Debatte: Journal of Contemporary Central and Eastern Europe, 16(3), 291-308.

Wrench, J. (2004). Trade union responses to immigrants and ethnic inequality in Denmark and the UK: The context of consensus and conflict. European Journal of Industrial Relations, 10(1), 7-30.

Wrench, J. (2007). Gathering evidence for racism and discrimination in the EU: The implications for trade unions. Transfer: European Review of Labour and Research, 3(3), 488-496.

Zincone, G. (2011). The case of Italy. In G Zincone, M Borkert, \& R Penninx (Eds.), Migration policymaking in Europe; The dynamics of actors and contexts in past and present (pp. 247-290). Amsterdam: Amsterdam University Press. 